A

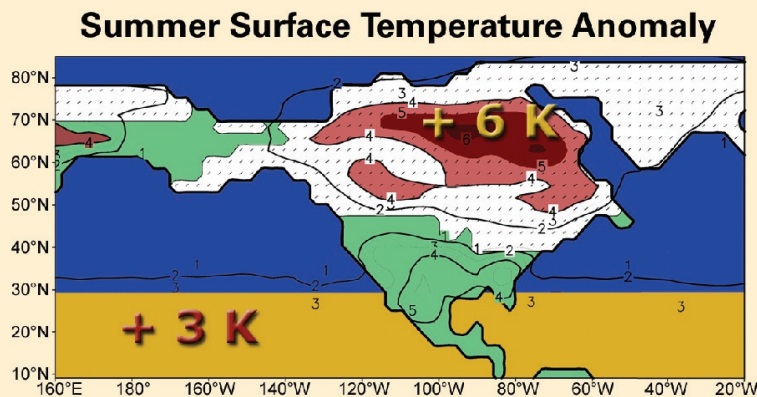

B

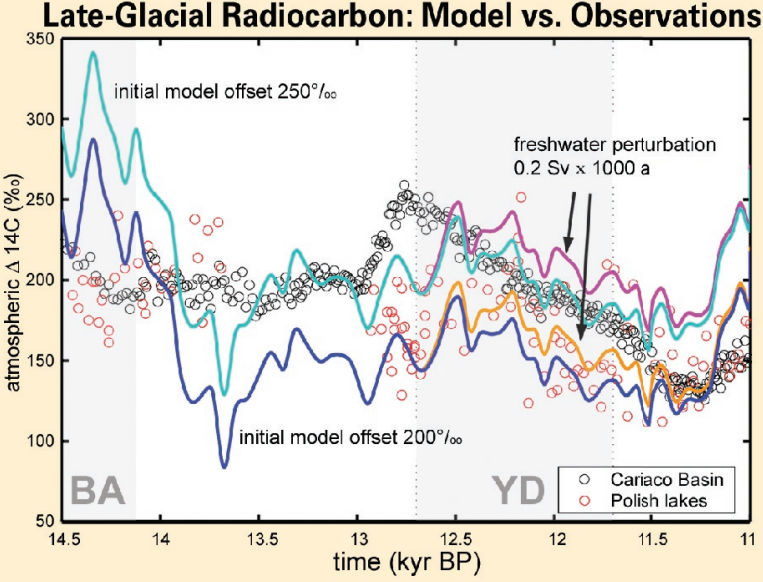

Fig. 2: Deglaciation. (a) The role of the tropics in the melting and reforming of the Laurentide Ice Sheet on glacial timescales is analyzed by an atmospheric general circulation model. It is found that warming of tropical SSTS from glacial boundary conditions causes a large increase in summer temperatures centered over the ice-sheet-forming regions of Canada. (b) Temporal evolution of the atmospheric radiocarbon concentration $\delta^{14} \mathrm{C}$ during the Late Glacial period. Circles denote values inferred from sediment data (data sources: Cariaco Basin: Hughen et al., 2000; Polish lakes: Goslar et al., 2000). The curves are model results, obtained with an ocean general circulation model coupled to an atmospheric reservoir (Buzin et al., 2004), which is also subject to changes in cosmogenic ${ }^{14} \mathrm{C}$ production las estimated by Marchal et al., 2001). The simulations started at 17 kyr BP using different initial values, as there is consider able uncertainty regarding the atmospheric radiocarbon concentration at that time (e.g., see Goslar, 2001). If an initial value of $250 \%$ is assumed, the model agrees over longer periods with the Cariaco Basin derived $\delta^{14} \mathrm{C}$ history; starting with $200 \%$ yields better agreement with the varved lake-sediment record from Poland. Both simulations do not reproduce the steep increase of atmospheric radiocarbon at the beginning of the Younger Dryas cold period (YD), even in the case where deepwater formation in the North Atlantic is shut down by a meltwater perturbation. Conversely, for the Bølling/Allerød warm phase (BA) the model suggests elevated atmospheric values that do not show up in the geological records.

Romanova et al., 2004). The results may help to assess the effect of iceberg invasions and meltwater events, suggesting that the THC is prone to instability during a degla- ciation phase. However, modeling results indicate several mismatches between modeled and reconstructed ${ }^{14} \mathrm{C}$ concentration (Fig. 2b). One is possibly linked to an abrupt onset of vigorous deepwater formation during the Bølling warm period.

\section{Conclusions and Outlook}

Teleconnections and their role in long-term climate variability are investigated using numerical models of the Earth's system. To reconstruct climate change over thousands of years, it is necessary to use the evidence provided by sediments, ice cores, pollen data, fossil and isotope records (e.g. Rühlemann et al., 2004; Felis et al., 2004). Analyzing paleoclimatic records and models in tandem enables the evaluation of climate transitions and the analysis of forcing and feedback mechanisms of glacial-interglacial and future climate changes.

\section{REFERENCES}

Felis, T., Lohmann, G., Kuhnert, H., Lorenz, S., Scholz, D. Pätzold, J., Al-Rousan, S.A. and Al-Moghrabi, S.M., 2004: Increased seasonality in Middle East temperatures during the last interglacial period. Nature 429, 164-168.

Knorr, G., and Lohmann, G., 2003: Resumption of the Atlantic conveyor circulation via Southern Ocean warming during deglaciation. Nature 424, 532-536. Lohmann, G., Rimbu, N. and Dima, M., 2004: Climate signature of solar irradiance variations: Analysis of long-term instrumental, historical, and proxy data. International. Journal of Climatology 24 (8) 1045-1056. doi: 10.1002/joc.1054.

Rimbu, N., Lohmann, G., Felis, T., and Pätzold, J., 2003: Shift in ENSO teleconnections recorded by a Red Sea coral. J. Climate 16, 1414-1422.

Rodgers, K., Lohmann, G., Lorenz, S., Schneider, R., and Henderson, G., 2003: A tropical mechanism for Northern Hemisphere deglaciation. Geochem., Geophys., Geosyst. 4, 1046, doi: 10.1029/ 2003GC0000508

For full references please consult: www.pages-igbp.org/products/newsletters/ref2004_2.html

\title{
Tree-Rings, Isotopes, Climate and Environment: TRICE
}

\section{G. Helle ${ }^{1}$ and 0. Panferov}

${ }^{1}$ Forschungszentrum Jülich GmbH, ICG-V: Sedimentary Systems, 52425 Jülich, Germany; g.helle@fz-juelich.de ${ }^{2}$ Georg-August-University Göttingen, Inst. of Bioclimatology, Büsgenweg 2, 37077 Göttingen, Germany

Tree-rings from temperature-limited sites provide low frequency climate proxy data for the last 1000 years (e.g. Esper et al. 2002). However, it is still unclear to what extent and by what processes climatic signals are exactly mirrored in the tree-ring archive. An improved knowledge of tree-ring response to current climate forc- ing is, thus, imperative to advance predictions in climate change.

The TRICE project (www.triceproject.de) uses stable carbon and oxygen isotopes as a) indicators for processes underlying tree growth and b) climate proxies. Thus, TRICE investigates the impact of changing environmental quantities on tree growth.
Mechanistic modeling and novel transfer functions, combining tree-ring proxies (ring width, wood density, isotopes) help to develop measures for tracing Holocene climate variability from the tree-ring archive.

Trees are located at the junction of the water cycle, which controls the distribution of pre- 


\section{Science Highlights: DEKLIM}

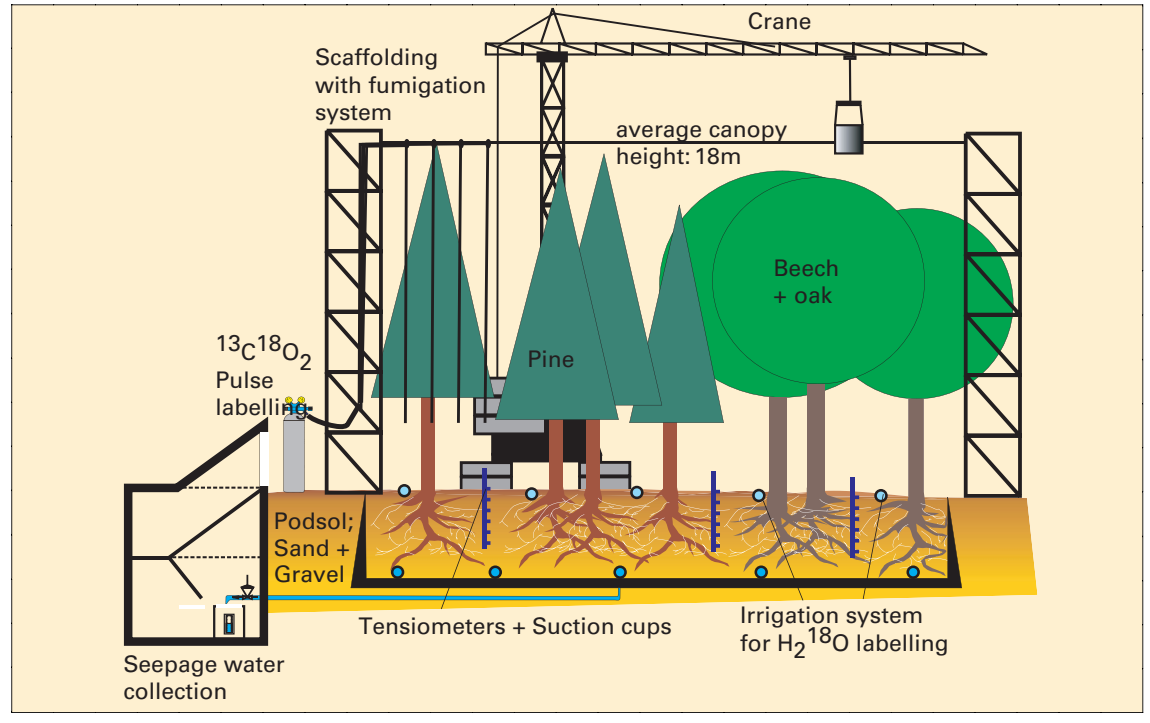

Fig. 1: Scheme of the experimental set-up for isotope studies in the aboreal system at the Forest Lysimeter Facility in St. Arnold, NW-Germany.

cipitation waters into the surface or subsurface run-off systems and the return of water by means of evapotranspiration. The temporal dynamics of changes at this junction are stored by tree-ring stable isotope proxies.

Therefore, 10 German tree sites were selected providing annually resolved time series for verifying carbon isotope discrimination and tracing meteoric waters as spatial measures of climate and air mass variability. This is part of a network of 25 European sites from the EU-project ISONET (www.isonet-online.de) to assess local to regional impacts of global change.

TRICE focuses on the climatic signature conservation related to carbohydrate allocation in trees. Investigations are carried out on a large-scale forest lysimeter in St. Arnold, NW-Germany (Fig. 1), which provides 40 years of data on the hydro-climatic cycle. Novel free-air fumigation- and irrigation-systems allow simultaneous labeling with ${ }^{13} \mathrm{CO}_{2}$ and $\mathrm{H}_{2}{ }^{18} \mathrm{O}$ under ambient and elevated atmospheric $\mathrm{CO}_{2}$ to trace the fate of stable isotopes in trees.

$\delta^{13} \mathrm{C}$ measurements revealed a seasonally recurring tri-phase pattern (Fig. 2). This pattern cannot, however, be explained by the currently used model of carbon discrimination; it is inadequate (Francey \& Farquhar 1982) since the $\delta^{13} \mathrm{C}$-pattern is dominated by post-photosynthetic physiological processes (Helle \& Schleser 2004), even though changing meteoro- logical conditions can be deduced from the $\delta^{13} \mathrm{C}$ pattern. Figure 2 shows the intra-annual carbon isotope distribution of oak treerings including monthly means of temperature and precipitation for the years 1957 and 1958. June and July of 1957 were particularly dry and warm. Thus, photosynthates of high ${ }^{13} \mathrm{C}$ content were produced by the leaves, causing a slow decline of $\delta^{13} \mathrm{C}$ across the latewood. In 1958, $\delta^{13} \mathrm{C}$-values immediately fell to a minimum at the end of earlywood (EW). Latewood shows no significant
${ }^{13} \mathrm{C}$ variations, since the weather conditions during these summer months varied little. Note, that the tree-ring from 1958 is $12 \%$ wider than the ring formed in 1957. This demonstrates that changes in seasonal growth can be detected merely from the shape of intra-annual $\delta^{13} \mathrm{C}$ patterns.

The results reveal the large potential of high resolution stable isotope data for studies on seasonality from tree-rings. Similar studies on tropical trees with indistinct growth-rings revealed annual patterns (Verheyden et al. 2004). These investigations show that cross-dating tropical wood and tracking ENSO signals back to pre-instrumental times might also be possible by using these techniques.

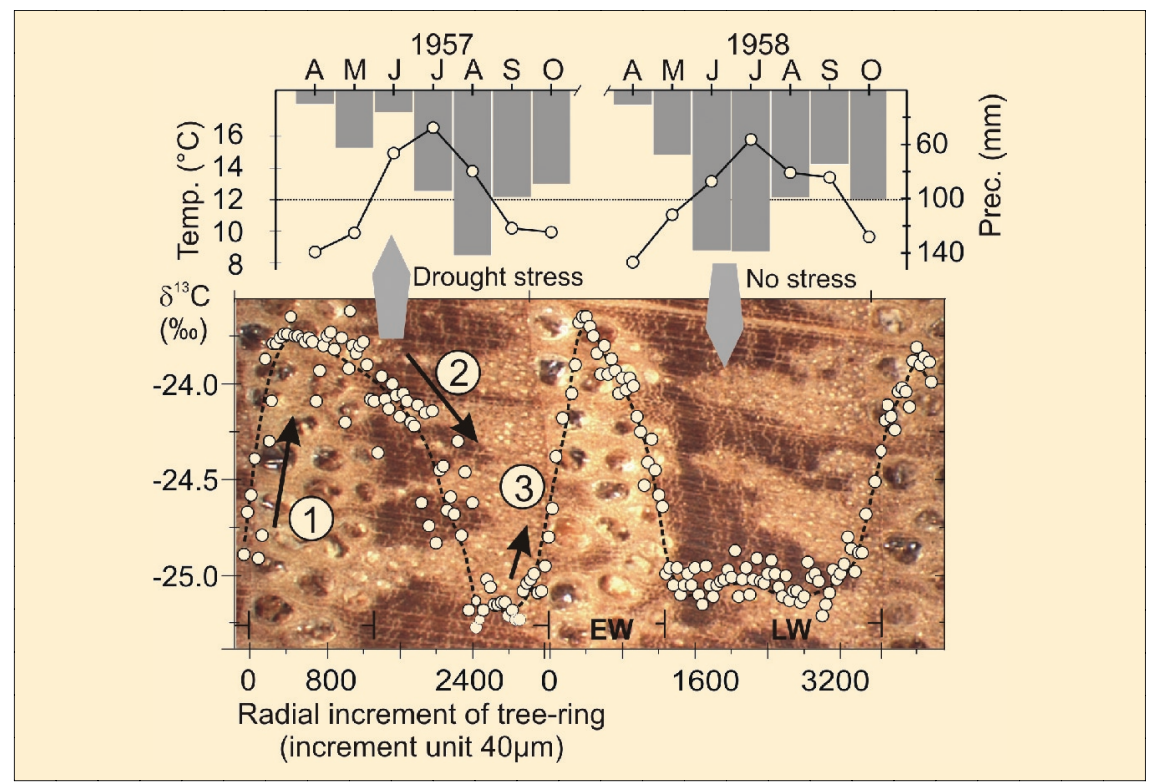

Fig. 2: Tri-phase intra-annual carbon isotope pattern of two oak tree-rings and corresponding monthly mean values of measured temperature and precipitation, revealing the impact of changing climatic variables on the midsection of the seasonal $\delta^{13} \mathrm{C}$-pattern.

\section{REFERENCES}

Esper, J., Cook, E. and Schweingruber, F.H., 2002: Low-Frequency Signals in Long Tree-Ring Chronologies for Reconstructing Past Temperature Variability. Science 295, 2250-2253.

Francey, R. J. and Farquhar, G.D., 1982: An explanation of ${ }^{13} \mathrm{C} /{ }^{12} \mathrm{C}$ variations in tree rings. Nature $\mathbf{2 9 7}$, 28-31

Helle, G. and Schleser, G.H., 2004: Beyond $\mathrm{CO}_{2-}$ fixation by Rubisco - an interpretation of ${ }^{13} \mathrm{C} /{ }^{12} \mathrm{C}$ variations in tree rings from novel intra-seasonal studies on broad-leaf trees. Plant, Cell \& Environment 27, 367-380

Verheyden, A., Helle, G., Schleser, G.H., Dehairs, F, Beeckman, H. and Koedam, N., accepted: Annual cyclicity in high-resolution stable carbon and oxygen isotope ratios in the wood of the mangrove tree Rhizophora mucronata. Plant, Cell \& Environment. 